\title{
A family with mental retardation, variable macrocephaly and macro-orchidism, and linkage to Xq12-q21
}

\author{
J P Johnson, R Nelson, C E Schwartz
}

\begin{abstract}
A family with $X$ linked inheritance of mental retardation (XLMR) is presented. There are 10 mentally retarded males and two affected females in two generations. There are four obligatory carriers, one of whom is described as "slow". Most affected males show macrocephaly and macro-orchidism, which are typical signs of the fragile $X$ syndrome, but have been tested cytogenetically and by analysis of the FMR1 gene and do not have this syndrome. However, some normal males in the family also exhibit macroorchidism and macrocephaly. Linkage analysis using markers derived from the $X$ chromosome indicates that the causative gene in this family is located in the proximal long arm of the $X$ chromosome, in the interval Xp11-q21. Maximum lod scores of 2.96 with no recombination were found at three loci in Xq13-q21: DXS1111, DXS566, and DXS986. Recombination was observed with DXS1002 (Xq21.31) and DXS991 (Xp11.2), loci separated by about $30 \mathrm{Mb}$. Although isolation of the gene in this family will be difficult because of the size of the region involved, the localisation should be helpful in investigating other similar families with XLMR, macrocephaly, and macro-orchidism not attributable to FMR1.
\end{abstract}

$(\Im$ Med Genet 1998;35:1026-1030)

Department of Medical Genetics, Shodair Hospital, PO

Box 5539, Helena, MT 59604-5539, USA J P Johnson

Greenwood Genetic Center, Greenwood, SC, USA

R Nelson

C E Schwartz

Correspondence to: Dr Johnson.

Received 12 February 1998 Revised version accepted for publication 14 May 1998
Keywords: $\mathrm{X}$ linked mental retardation; XLMR; macro-orchidism; mental retardation

Non-specific $X$ linked mental retardation (NSXLMR) is a clinical entity presenting difficulties in categorisation because of lack (by definition) of an associated phenotype other than mental retardation. ${ }^{12}$ Linkage data are now available for over 40 NSXLMR families, with unique genes (denoted as MRX with unique numbers) potentially responsible for the mental retardation in each family. ${ }^{3}$ However, overlapping linkage results indicate that only a few of these genes map to exclusive locations. ${ }^{45}$
Early in the development of the clinical definition of fragile $\mathrm{X}$ syndrome, there was recognition that macro-orchidism, one of the cardinal associated findings, could also occur in NSXLMR males not manifesting $X$ chromosome fragility. ${ }^{6-8}$ In addition, macrocephaly is a common finding in XLMR. ${ }^{9}$ There are more recent reports of similarly affected subjects and families. ${ }^{10-12}$ The terms fragile $\mathrm{X}$ negative Martin-Bell syndrome, ${ }^{13}$ mental retardationmacro-orchidism, $\mathrm{X}$ linked $\left(\mathrm{MRMO}^{14}\right)$, or $\mathrm{XLMR}+\mathrm{MO}^{15}$ (McKusick MIM No 309530) have been used to describe these families.

We describe a family with macrocephaly and macro-orchidism associated with XLMR in which some retarded males do not have both macrocephaly and macro-orchidism, but some unaffected males do. We present linkage data indicating that the causative gene is in the $\mathrm{Xp} 11-\mathrm{q} 21$ region.

\section{Subjects and methods}

FAMILY

This family was ascertained when subjects III.15, III.18, and III.20 were evaluated because III.13 wished to know her risk of having an affected son (fig 1). There are 10 mentally retarded males in two generations of this family, with two retarded females and 10 unaffected males (one male of uncertain phenotype died at 3 months of pneumonia). The inheritance of the mental retardation is consistent with $\mathrm{X}$ linked mental retardation (XLMR). Of interest, but presumably unrelated, is the fact that II. 5 had neurofibromatosis (NF) and died of an islet cell carcinoma of the pancreas. None of the people we examined personally showed any signs of NF and this includes five of the affected males.

Clinical information for six of the affected and five of the unaffected males was available. Findings for these males and for five at risk females are summarised in table 1 . Fragile $X$ cytogenetic studies on the three index males were negative on two occasions in two different laboratories. FMR1 studies (not shown) by polymerase chain reaction and Southern blotting showed normal results on affected males. Intelligence was assessed by examination, report, or by IQ score when available. The IQ 


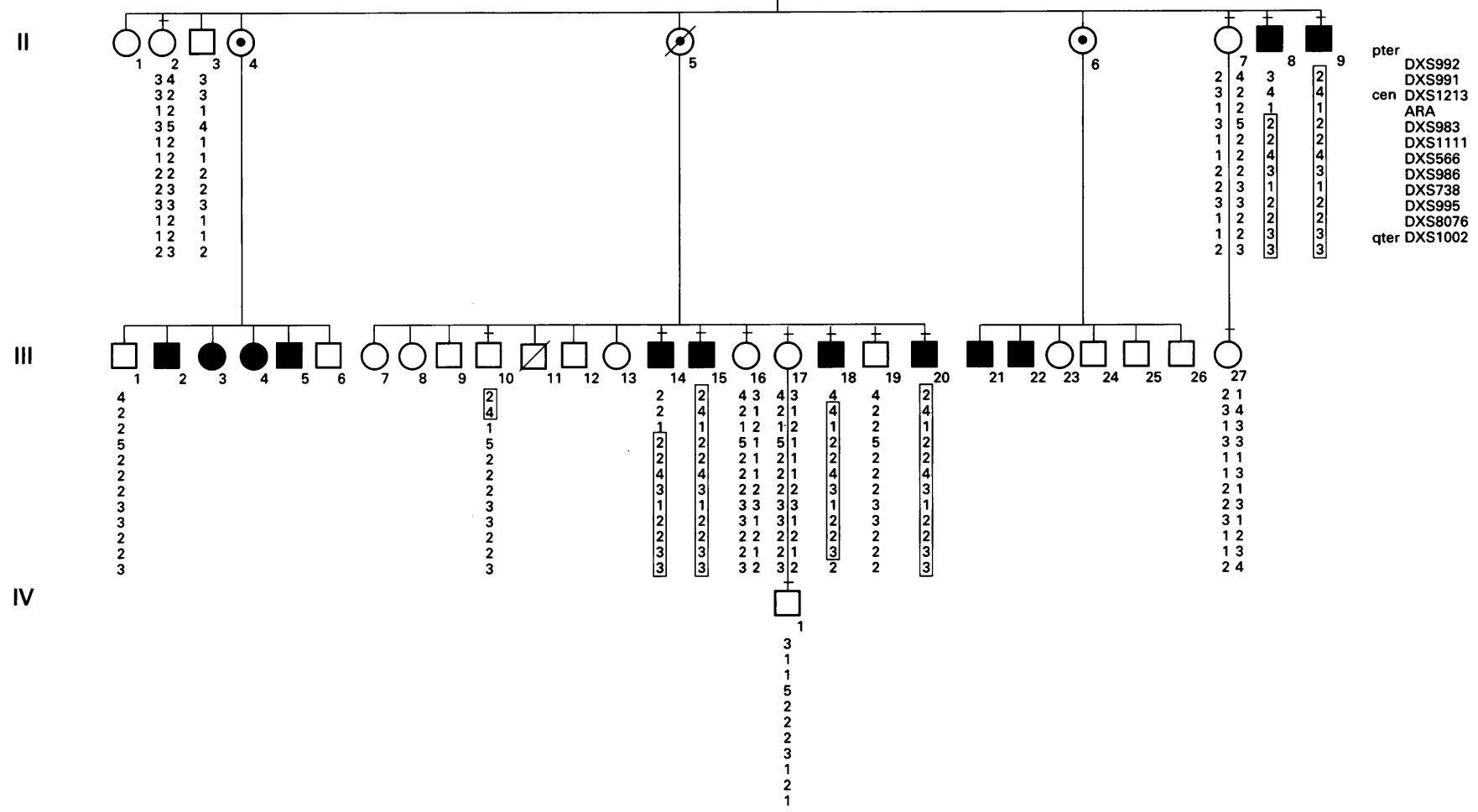

Figure 1 Partial pedigree of XLMR family. Only critical subjects are shown and not necessarily in order of age. Haplotypes for the indicated DNA markers are shown beneath pedigree symbols. Boxed portions of the haplotype segregate with mental retardation in affected males.

scores available for four of the affected males are remarkably consistent and fall within the range of moderate mental retardation. Four of the affected males have macro-orchidism with testicular volumes $>35 \mathrm{ml}$. Volumes were estimated using a published formula. ${ }^{7}$ One mentally retarded male (III.15) has testes of normal volume $(23 \mathrm{ml}$, normal upper limit $25-35 \mathrm{ml})$, and one was not examined. Surprisingly, two of the unaffected males (II.3 and III.19) also have testicular volumes $>35 \mathrm{ml}$. Five of six examined affected males also have macrocephaly

Table 1 Clinical data

\begin{tabular}{llllllll}
\hline No & Age & Sex & OFC (cm) & OFC (\%) & Height (in) & Testes (ml) & $I Q$ \\
\hline II.1 & $40 \mathrm{~s}$ & F & & & & NA & NL \\
II.2 & 69 & F & & & & NA & NL \\
II.3 & 72 & M & 59 & $>98$ & 67.5 & 98 & NL \\
II.8 & 58 & M & 59 & $>98$ & & 58 & MR \\
II.9 & 56 & M & 58.5 & 98 & & 49 & MR \\
III.1 & 39 & M & & & 71 & 32 & NL \\
III.10 & 33 & M & & & 66 & 32 & NL \\
III.13 & 29 & F & 57.5 & 98 & & NA & NL \\
III.14 & 27 & M & 56 at 6 y & $>98$ & & & 35 \\
III.15 & 26 & M & 58 & 90 & 71 & 23 & 43 \\
III.16 & 23 & F & 56 & 75 & & NA & NL \\
III.17 & 25 & F & 54 & 25 & & NA & NL \\
III.18 & 22 & M & 54 & 25 & & 54 & 43 \\
III.19 & 18 & M & 58.5 & 98 & 67.5 & 38 & NL \\
III.20 & 17 & M & 61 & $>98$ & & 38 & 38 \\
IV.1 & 7 & M & 53 & 75 & 47 & 2 & NL \\
\hline
\end{tabular}

OFC: occipitofrontal circumference, \%: centile, in: inches, $\mathrm{cm}$ : centimetres, IQ: intelligence quotient, NA: not applicable, NL: normal intelligence, MR: mentally retarded. Blanks indicate data are not available for the particular measure. with occipitofrontal circumferences (OFC) of $>90$ th centile. The same two unaffected males (II.3 and III.19) have similar OFCs, as does an at risk female, III.13. Two presumably affected females are described as "slow" and are living with their parents as adults (III.3 and III.4). The carrier mother (II.4) is also described as "slow" (this branch of the family was unavailable for detailed study, as was the branch from II.6). The affected males have monotonous but not repetitive or "jocular" speech, blue eyes with dark hair, and a triangular facial appearance with some prominence of the jaw (fig 2), but no facial elongation or lateral prominence of the ears, which would be more reminiscent of the fragile $\mathrm{X}$ syndrome. Two affected males (II.8 and III.15) have a seizure disorder, as does an unaffected male, IV.1. The personality is outgoing without autistic characteristics, there is normal eye contact, and there are no hand flapping movements or self-abuse.

DNA ANALYSIS

The linkage project was approved by appropriate reviewers (see Acknowledgments) and informed consent was obtained from sampled people. DNA was isolated from leucocytes in standard fashion. Polymerase chain reaction (PCR) was accomplished using a Perkin Elmer 9600 thermocycler. The X chromosome markers spanning $\mathrm{Xp22.31}$ to $\mathrm{Xq28}$, for which 

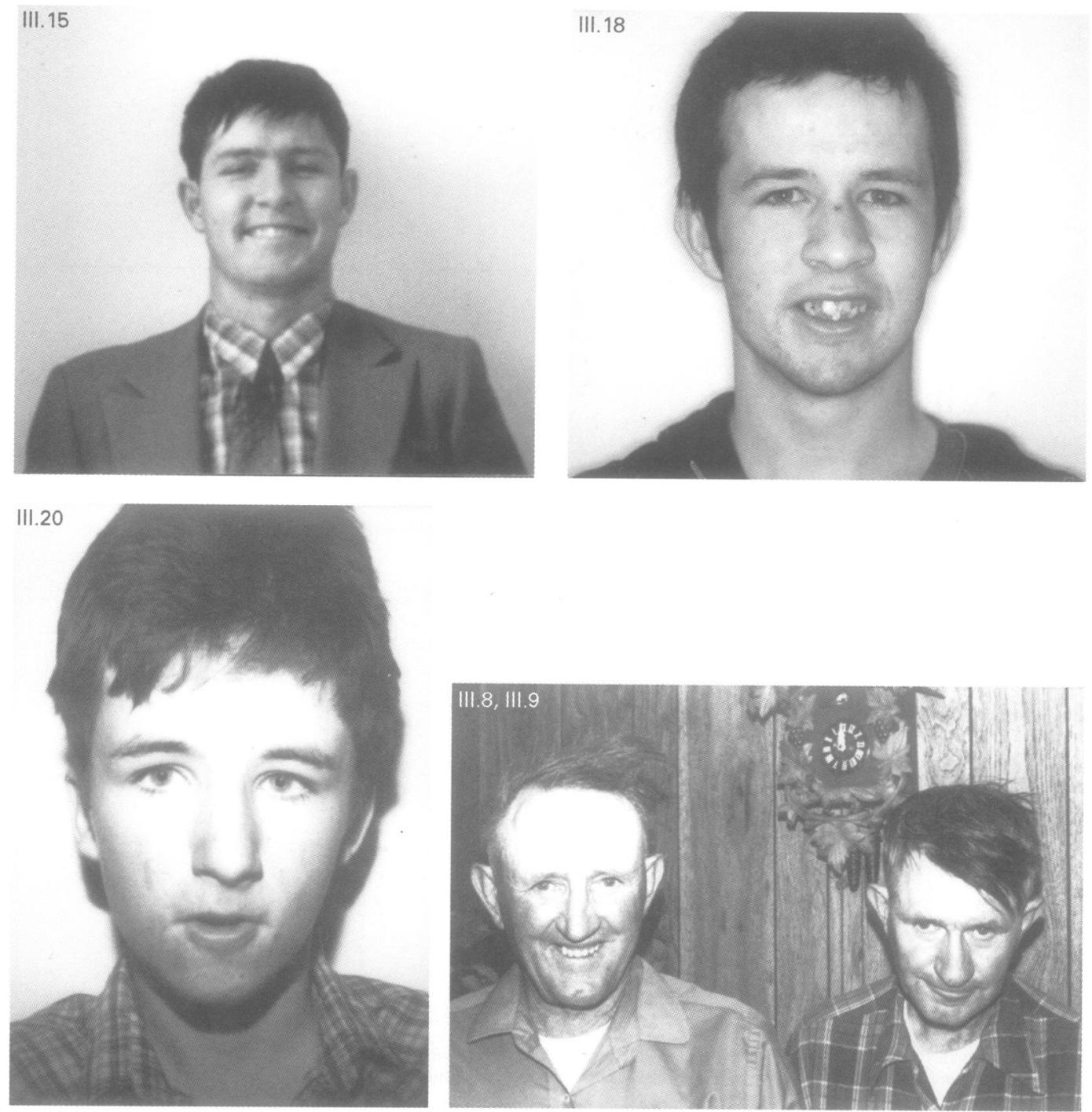

Figure 2 Affected males as indicated on the pedigree (fig 1). (Photographs reproduced with permission.)

inheritance in this family was analysed, are listed in table 2. Primers for the microsatellite markers were FAM labelled on a Beckman Oligo synthesiser using primer sequences from the Genome Data Base (GDB, Baltimore).

The total volume for each PCR reaction was $20 \mu \mathrm{l}$. The reactions contained $100 \mathrm{ng}$ DNA, 1 $\mu \mathrm{mol} / \mathrm{l}$ of each primer, $1 \times \mathrm{Mg}$ buffer, 0.2 $\mathrm{mmol} / 1 \mathrm{dNTPs}$, and 1/10 unit of Taq polymerase. Ten $\mu l$ of the PCR product from each reaction were mixed with $2 \mu$ lof bromophenol blue dye and loaded on $2 \%$ agarose gels in $1 \times$ TBE buffer. Following electrophoresis to visualise results, the products were diluted and loaded onto an ALF (Pharmacia) gel for size analysis.

Allelic inheritance was interpreted with reference to CEPH control 133402, family members, marker standards, and published data. Linkage of the mental status phenotype (with "affected" being mentally retarded, regardless of associated macrocephaly or macro-orchidism) to alleles for the DNA

Table $2 X$ chromosome markers and linkage results

\begin{tabular}{|c|c|c|c|c|c|c|c|c|c|c|}
\hline \multirow[t]{2}{*}{ Marker } & \multirow[t]{2}{*}{ Locus } & \multirow[t]{2}{*}{ Location } & \multicolumn{6}{|c|}{ Recombination } & \multirow[t]{2}{*}{$\theta \max$} & \multirow[t]{2}{*}{$Z \max$} \\
\hline & & & 0.001 & 0.01 & 0.05 & 0.1 & 0.2 & 0.3 & & \\
\hline AFM120Xa9 & DXS987 & $\mathrm{Xp22.31}$ & -11.82 & -6.84 & -3.45 & -2.08 & -0.86 & -0.31 & 0.50 & 0.00 \\
\hline AFM184xg5 & DXS992 & $\mathrm{Xp} 21.3$ & -9.04 & -5.07 & -2.39 & -1.34 & -0.46 & -0.10 & 0.43 & 0.03 \\
\hline AFM151xf6 & DXS991 & $\mathrm{Xp} 11.21$ & -3.04 & -1.08 & 0.17 & 0.57 & 0.72 & 0.58 & 0.19 & 0.73 \\
\hline ARA & ARA & $\mathrm{Xq12}$ & 2.95 & 2.91 & 2.72 & 2.47 & 1.93 & 1.31 & 0.00 & 2.96 \\
\hline AFM078za1 & DXS983 & $\mathrm{Xq12}$ & 0.67 & 0.66 & 0.61 & 0.55 & 0.40 & 0.23 & 0.00 & 0.67 \\
\hline DXS1111 & DXS1111 & Xq12 & 2.95 & 2.91 & 2.70 & 2.44 & 1.87 & 1.25 & 0.00 & 2.96 \\
\hline HX60 & DXS566 & Xq13.3 & 2.95 & 2.91 & 2.71 & 2.45 & 1.89 & 1.27 & 0.00 & 2.96 \\
\hline AFM1 16xg1 & DXS986 & $\mathrm{Xq} 21.1$ & 2.95 & 2.91 & 2.71 & 2.45 & 1.90 & 1.28 & 0.00 & 2.96 \\
\hline DXS738 & DXS738 & $\mathrm{Xq} 21.1$ & 2.95 & 2.91 & 2.72 & 2.47 & 1.92 & 1.30 & 0.00 & 2.96 \\
\hline AFM207zg5 & DSX995 & Xq21.1 & 0.85 & 0.83 & 0.77 & 0.69 & 0.50 & 0.29 & 0.00 & 0.85 \\
\hline AFM6357Xe5 & DXS8076 & $\mathrm{Xq} 21.1$ & 2.94 & 2.91 & 2.72 & 2.47 & 1.93 & 1.31 & 0.00 & 2.96 \\
\hline AFM249vh5 & DXS1002 & $\mathrm{Xq} 21.31$ & -0.03 & -0.03 & -0.02 & -0.10 & 0.00 & 0.00 & 0.39 & 0.00 \\
\hline AFM136yc7 & DXS990 & $\mathrm{Xq21.33}$ & -0.05 & 0.92 & 1.43 & 1.51 & 1.32 & 0.97 & 0.09 & 1.51 \\
\hline XL5A & DXS424 & $\mathrm{Xq} 23$ & -4.93 & -2.93 & -1.56 & -0.98 & -0.46 & -0.19 & 0.50 & 0.00 \\
\hline AFM248we5 & DXS1001 & $\mathrm{Xq} 24$ & -14.74 & -8.76 & -4.67 & -2.98 & -1.44 & -0.67 & 0.50 & 0.06 \\
\hline & DXS548 & Xq27.3 & -7.88 & -4.90 & -2.92 & -2.14 & -1.40 & -0.86 & 0.50 & 0.60 \\
\hline sDF-2 & DXS1108 & $\mathrm{Xq} 28$ & -15.04 & -9.06 & -4.97 & -3.28 & -1.72 & -0.89 & 0.50 & 0.52 \\
\hline
\end{tabular}


markers was assessed by the FASTLINK modification of the LINKAGE program. ${ }^{1617}$ Penetrance was assigned at 1.0 for mental retardation associated with the affected allele. Assignment of penetrance for females is a moot issue, as none of the four females genotyped inherited the "affected" haplotype.

\section{Results}

Linkage analysis results are shown in table 2 Three loci (DXS1111, DXS566, and DXS986) show linkage to the mental retardation phenotype in males at a maximum lod score of 2.96 with no recombination. Given the known map positions for these loci, the gene causing NSXLMR in this family is localised between Xp11 and Xq21. The region is flanked by the loci DXS991 in Xp11.2 and DXS1002 in Xq21.31, which show recombination and are separated by about $30 \mathrm{Mb}$. Alleles for the markers are shown in inferred haplotypes on the pedigree (fig 1). For loci DXS983, DXS1111, DXS566, DXS986, DSX738, and DXS995, respectively, the haplotype 2-4-3-12-2 is observed in all affected males. The at risk female with macrocephaly, III.13, does not share this haplotype, indicating that her macrocephaly is probably not a manifestation of carrier status. Similarly, III.17, who has a son with seizures, does not carry this haplotype, indicating that her son's seizures are probably unrelated to the XLMR allele in the family.

\section{Discussion}

The gene causing XLMR in this family is most probably located in the proximal $\mathrm{Xq}$ region. This positioning shows considerable overlap with results from other families with XLMR, including MRX 1, 4, 5, 6, 7, 8, 9, 13, 14, 17, 20, $22,26,30$, and $31 .^{3-5}$ In addition, specific XLMR genes for Menkes disease, ${ }^{18}$ PGK deficiency, ${ }^{19}$ and $\alpha$ thalassaemia/mental retardation (ATR-X), ${ }^{20}$ and for other syndromes ${ }^{21-29}$ map to this region. ${ }^{3}$ These latter syndromes are generally excluded in this family by lack of consistent clinical findings. Of the two recent reports of families with macro-orchidism, the family investigated by $\mathrm{Hu}$ et $a l,{ }^{11}$ with the causative gene designated MRX2, maps to $\mathrm{Xp21-22}$, excluding overlap with the family in our report. Affected subjects in this previously reported family are similar to the males described here, with macrocephaly and macroorchidism, but also with prominent ears. There is no map information for the family described by Tariverdian et al. ${ }^{10}$ However, this seems to be a different condition with males manifesting prominent eyebrows and jaws and abnormal ears in addition to macro-orchidism. Mutations in the ATR-X gene can produce multiple phenotypes, and therefore this is a "candidate" causative gene for the family described in our report. Potential identity with one of the other MRX genes cannot be excluded. Until the causative genes are isolated, correct designation of the location and number of XLMR genes cannot be defined.

In this family, although the physical phenotype in affected relatives somewhat resembles that in patients with the fragile $\mathrm{X}$ syndrome, the characteristics contributing to this impression are inherited irregularly, with some unaffected males exhibiting macro-orchidism or macrocephaly or both, and one at risk female (with a non-carrier haplotype) showing macrocephaly. One explanation is that macroorchidism and macrocephaly segregate coincidentally in this family. A similar family with macrocephaly, XLMR, and mild retardation in heterozygous females has been described by Turner et $a l,{ }^{9}$ with linkage to the pericentromeric region. This location overlaps the Xp11q21 location of the family described here. Isolation of the causative gene and investigation of other similar families will assist in correct categorisation of the XLMR conditions in this and other similar families.

We thank the family and their physicians for cooperation in obtaining the data and samples necessary for this study. The obtaining the data and samples necessary for this study. The Mental Retardation Association of Utah, Project Action for the
Retarded, and the Utah Division of Services to the HandiRetarded, and the Utah Division of Services to the Handi-
capped all provided approval of the project. This work was supcapped all provided approval of the project. This work was supported, in part, by a grant from the South Carolina Department of Disabilities and Special Needs, and by the Howard Hughes Research Institute (HHMI) at the University of Utah. We thank of HHMI for their logistical support and expert advice in performance of this study.

1 Turner G, Turner B. X-linked mental retardation. 7 Med Genet 1974;11:109-13.

2 Herbst DS. Nonspecific X-linked mental retardation 1: review with information from 24 new families. $A m \mathcal{F} M e d$ Genet 1980;7:443-60.

3 Lubs HA, Chiurazzi P, Arena JF, Schwartz C, Tranebjaerg, Neri G. XLMR genes: update 1996. Am $\mathcal{F}$ Med Genet 1996; 64:147-57

4 Gedeon AK, Donnelly AJ, Mulley JC, Kerr B, Turner G. How many X-linked genes for non-specific mental retardation (MRX) are there? Am f Med Genet 1996;64:158-62.

5 Hane B, Schroer RJ, Arena JF, Lubs HA, Schwartz CE, Stevenson RE. Nonsyndromic X-linked mental retardation: review and mapping of MRX29 to Xp21. Clin Genet 1996; 50:176-83.

6 Jennings M, Hall JG, Hoehm H. Significance of phenotypic and chromosomal abnormalities in X-linked mental retardation (Martin-Bell or Renpenning syndrome). Am $\mathcal{F}$ Med Genet 1980;7:417-32.

7 Nielson KB, Tommerup N, Dyggve HV, Schou C. Macroorchidism and fragile $\mathrm{X}$ in mentally retarded males. Hum Genet 1982;61:113-17.

8 Fishburn J, Turner G, Daniel A, Brookwell R. The diagnosis and frequency of $\mathrm{X}$-linked conditions in a cohort of moderately retarded males with affected brothers. $\mathrm{Am} f$ Med Genet 1983;14:713-24.

9 Turner G, Gedeon A, Mulley J. X-linked mental retardation with heterozygous expression and macrocephaly: pericentromeric gene localization. Am $\mathcal{F}$ Med Genet 1994;51:57580

10 Tariverdian G, Froster-Iskenius U, Deuschl G, Wolff G. Mental retardation, acromegalic face and megalotestes in two half-brothers: a specific form of X-linked mental retardation without fra(X)q? Am $\mathcal{F}$ Med Genet 1991;38:208-11.

$11 \mathrm{Hu}$ LJ, Blumenfield-Heyberger S, Hanauer A, Weissenbach Hu L, Blumenfield-Heyberger S, Hanauer A, Weissenbach linkage analysis in MRX 2 and MRX 4 families revisited. linkage analysis in MRX2 and $M$

12 Chiurazzi P, de Graaff E, Ng J, et al. No apparent involvement of the FMR1 gene in five patients with phenotypic manifestations of the fragile $\mathrm{X}$ syndrome. $\mathrm{Am} \mathcal{F} \mathrm{Med}$ Genet 1994;51:309-14.

13 Opitz JM, Sutherland GR. International workshop on the fragile X and X-linked mental retardation. Am $\mathcal{F}$ Med Gene 1984;17:5-94.

14 Howard-Peebles PN, Finley WH. Screening of mentally retarded males for macro-orchidism and the fragile $\mathrm{X}$ chromosome. Am F Med Genet 1983;15:631-5.

15 McKusickVA. Mendelian inheritance in man: catalogs of autosomal dominant, autosomal recessive, and $X$-linked phenotypes. Baltimore: The Johns Hopkins University Press, 1994.

16 Cottingham RW Jr, Idury RM, Schaffer AA. Faster sequential genetic linkage computations. Am $\mathfrak{f}$ Hum Genet tial genetic lin

17 Lathrop GM; Lalouel JM. Easy calculation of lod scores and genetic risks on small computers. Am $\mathcal{f}$ Hum Genet genetic risks
$1984 ; 36: 460-5$

18 Horn N, Stene J, Mollekaer AM, Friedrich U. Linkage studies in Menkes disease: the $\mathrm{Xg}$ blood group system and C-banding of the $\mathrm{X}$ chromosome. Ann Hum Genet 1984;48:161-72.

19 Sugie H, Sugie $Y$, Nishida M, et al. Recurrent myoglobinuria in a child with mental retardation: phosphoglycerate kinase deficiency. $\mathcal{f}$ Child Neurol 1989;4:95-9. 
20 Gibbons RJ, Picketts DJ, Villard L, Higgs DR. Mutations in a putative global transcriptional regulator cause X-linked
mental retardation with thalassemia. Cell 1995;80:837-45.

mental retardation with thalassemia. Cell 1995;80:837-45.
21 Porteous MEM, Johnson H, Burn J, et al. A new mental Porteous MEM, Johnson $\mathrm{H}$, Burn J, et al. A new mental
retardation syndrome mapping to the pericentromeric retardation syndrome mapping to the pericentromeric
region of the X-chromosome. Am f Hum Genet 1991;51: region
A106.

22 Fishbeck $\mathrm{KH}$, ar-rushdi $\mathrm{N}$, Rozear $M$, Pericak-Vance $M$, Fryns J. X-linked neuropathy: gene localization with DNA probes. Am $\mathcal{F}$ Hum Genet 1985;37:A153.

23 Goldblatt J, Ballo R, Sachs B, Moosa A. X-linked spastic paraplegia: evidence for homogeneity with a variable phenotype. Clin Genet 1989;35:116-20.

24 Schwartz CE, Ullmer J, Brown A, Pancoast I, Goodman HO, Stevenson RE. Allan-Herndon syndrome II. Linkage to

25 Wieacker $P$, Wolff $G$, Wienker TF. Close linkage of the
Wieacker-Wolff syndrome to the DNA segment DXYS1 in proximal Xq. Am $¥$ Med Genet 1987;28:245-53.

26 Schwartz CE, Ouzts Genet 1987;28:245-53. schwartz CE, Ouzts L, Gibson A, et al. Renpenning
syndrome: evidence for pericentric location of the gene in syndrome: evidence for pericentric location of the gene in two families, including the original Renpenning family. Paper presented at the 6th International Workshop of Fragile $X$
and X-linked Mental Retardation, Palm Cove, Australia, August 3-6, 1993

27 Gedeon A, Mulley J, Haan E. Gene localisation for Sutherland-Haan syndrome (SHS: MIM 309470). Am $\mathcal{F}$ Med Genet 1996;64:78-9.

28 Gedeon A, Mulley J, Turner G. Gene localisation for Wilson-Turner syndrome (WTS: MIM 309585). Am 7 Med Genet 1996;64:80-1.

29 Miles JH, Carpenter NJ. Unique X-linked mental retardation syndrome with fingertip arches and contractures linked to Xq21.31. Am ₹ Med Genet 1991;38:215-23. 